$\mathbf{T}$ he Materials Research Society is seeking nominations for the Von Hippel Award, the Turnbull Lectureship, the MRS Medal, and the Materials Theory Award. The deadline for nominations is April 1, 2013. These awards will be presented at the 2013 MRS Fall Meeting, December 1-6, in Boston.

The MRS awards program recognizes outstanding contributors to the progress

\section{MRS} of materials research. Nomination forms and details about eligibility and nomination criteria are available from the Materials Research Society website at www.mrs.org/awards.

\section{Von Hippel Award acknowledges outstanding interdisciplinary work in materials research}

The Von Hippel Award, first presented to Arthur R. von Hippel, whose interdisciplinary and pioneering research typified the spirit of the award, is the Society's highest honor. The recipient is recognized for brilliance and originality of intellect, combined with vision that transcends the boundaries of conventional scientific disciplines.

The award includes a $\$ 10,000$ cash prize, honorary membership in MRS, and a unique trophy - a mounted ruby laser crystal, symbolizing the manyfaceted nature of materials research.

\section{Turnbull Lectureship honors career of an outstanding researcher and communicator}

The David Turnbull Lectureship recognizes the career of a scientist who has made outstanding contributions to understanding materials phenomena and properties through research, writing, and lecturing, as exemplified by the life work of David Turnbull. While honoring the accomplishments of the recipient, the Turnbull Lectureship is intended to support and enrich the materials research community.

The recipient will give a technical lecture of broad appeal at a designated session of the 2013 MRS Fall Meeting. The Turnbull Lecturer will receive a $\$ 5,000$ honorarium and a citation plaque.

\section{MRS Medal recognizes recent discovery or advancement in materials science}

The MRS Medal offers public and professional recognition of an exceptional achievement by an individual in materials research. The Medal is awarded for a specific outstanding recent discovery (approximately last 10 years) or advancement that is expected to have a major impact on the progress of any materials-related field.

The award consists of a $\$ 5,000$ cash prize, an engraved and mounted medal, and a citation certificate.

\section{Materials Theory Award honors advances made in materials structure and behavior}

The Materials Theory Award recognizes exceptional advances made by materials theory to the fundamental understanding of the structure and behavior of materials. This award is intended to honor both those who have pioneered the development of a new theoretical approach and those who have used existing approaches to provide significant new insight into materials behavior.

The annual award consists of a $\$ 5,000$ cash prize, a presentation trophy, and a certificate. MRS acknowledges the generosity of Toh-Ming Lu and Gwo-Ching Wang in endowing this award.

\title{
YUCOMAT 2013 to be held in Herceg Novi
}

www.mrs-serbia.org.rs

$\mathbf{T}$ he Materials Research Society of Serbia will hold its Fifteenth Annual Conference (YUCOMAT 2013) on September 2-6, 2013, at Herceg Novi, Montenegro, under the auspices of the Federation of European Materials Societies (FEMS) and with endorsement from the Materials Research Society (MRS).

The conference will feature five symposia: Advanced Methods in Synthesis and Processing of Materials, Advanced Materials for High-Technology Application, Nanostructured Materials, Ecomaterials and Eco-technologies, and Biomaterials.
Invited plenary lectures along with oral and poster presentations are planned and awards will be given to researchers (preferably young members under the age of 35) of the best oral and poster presentation. Authors of highly rated $\mathrm{PhD}$ theses defended between two conferences will also be awarded. The benefits include free registration at the next YUCOMAT Conference. The official conference language is English.

The abstract deadline is May 1, 2013. The conference program will be sent to registered participants by midJuly 2013.
An exhibition of synthesis and characterization equipment and tutorials on especially interesting topics for young researchers are planned to be held during the conference. The venue will also include the traditional Cocktail Party on Monday evening and excursions on Wednesday (Dubrovnik, Croatia) and Thursday (Boka Kotorska Bay) afternoons.

More information on YUCOMAT 2013 is available on the official MRSSerbia website, www.mrs-serbia.org.rs or from Aleksandra Stojicic, Conference Secretary, yucomat@mrs-serbia.org.rs. 